\title{
TOP2B wt Allele
}

National Cancer Institute

\section{Source}

National Cancer Institute. TOP2B wt Allele. NCI Thesaurus. Code C50384.

Human TOP2B wild-type allele is located within 3p24 and is approximately $66 \mathrm{~kb}$ in length.

This allele, which encodes DNA topoisomerase 2-beta protein, plays a role in chromatin condensation and separation during DNA replication and transcription. 